\title{
DETERMINAN TINGKAT PENGETAHUAN IBU MENYUSUI TENTANG PEMBERIAN ASI EKSKLUSIF PADA BAYI 0-6 BULAN DI PUSKESMAS SUNGAI KAKAP TAHUN 2019
}

\author{
${ }^{1}$ Katarina Iit, ${ }^{2}$ Melyani
}

\author{
Akademi Kebidanan Panca Bhakti Pontianak \\ Email Korespendensi: katarinaiit17@gmail.com
}

\begin{abstract}
Abtrak
Pada tahun 2017 persentase bayi baru lahir yang mendapatkan ASI eksklusif sebesar 61,33\%. Angka tersebut sudah melampaui target renstra tahun 2017 yaitu 44\%. Persentase tertinggi cakupan pemberian ASI terdapat pada Nusa Tenggara Barat $(87,35 \%)$, sedangkan persentase terendah terdapat pada papua (15,32\%). Adapun ASI eksklusif adalah pemberian ASI saja pada bayi selama 0-6 bulan tanpa tambahan makanan dan minuman lain seperti susu formula, jeruk, madu, air teh. ASI dapat menurunkan angka kematian bayi karena meningkatkan daya imunitasnya sehingga lebih tahan terhadap penyakit. Hasil studi pendahuluan di Puskesmas Sungai Kakap ditemukan 32 ibu yang memberikan ASI eksklusif pada bayi 0-6 bulan. Tujuan penelitian adalah untuk mengetahui Determinan Tingkat Pengetahuan Ibu Tentang Pemberian ASI Secara Eksklusif Pada Bayi 0-6 bulan Di Puskesmas Sungai Kakap PadaTahun 2019. Desain penelitian ini menggunakan deskriptif dengan pendekatan cross sectional Populasi yaitu ibu yang menyusui bayi usia 0-6 bulan di wilayah kerja puskesmas sungai kakap sebanyak 107 responden. Instrumen yang digunakan dalam penelitian ini adalah kuesioner. Analisis yang digunakan dalam penelitian ini adalah analisis univariate dan Bivariate. Teknik sampel dalam penelitian ini menggunakan purposive sampling. Hasil Penelitian menjelaskan bahwa ada hubungan antara usia dengan Pemberian ASI Eksklusif dengan $\mathrm{P}$ value = 0,027, ada hubungan antara paritas dengan pemberian ASI Eksklusif dengan $\mathrm{P}$ value $=0,016$, ada hubungan antara Pendidikan dengan pemberian ASI Eksklusif dengan $\mathrm{P}$ value $=0,022$, ada hubungan yang bermakna antara Pengetahuan dengan pemberian ASI Eksklusif dengan $\mathrm{P}$ value $=0,040$, ada hubungan yang bermakna antara Pekerjaan dengan pemberian ASI Eksklusif dengan $\mathrm{P}$ value $=0,010$, ada hubungan yang bermakna antara dukungan suami dengan pemberian ASI Eksklusif dengan $\mathrm{P}$ value $=0,002$. Kesimpulan dari penelitian dapat disimpulkan bahwa Determinan tingkat pengetahuan ibu menyusui di wilayah kerja Puskesmas Sungai Kakap termasuk kategori sedikit dari responden.
\end{abstract}

Kata kunci: Pengetahuan, Ibu Menyusui, ASI Ekslusif exceeded the 2017 strategic plan target of $44 \%$. The highest percentage of breastfeeding coverage was found in Nusa Tenggara Barat $(87,35 \%)$, while the lowest percentage was in Papua $(15.32 \%)$. Exclusive breastfeeding is breastfeeding only for babies for 0-6 months without the addition of other foods and drinks such as formula milk, oranges, honey, tea water. Breast milk can reduce infant mortality because it increases immunity so that it is more resistant to disease. The results of a preliminary study at Sungai Kakap Public Health Center found that 32 mothers gave exclusive breastfeeding to infants 0-6 months. The research objective was to determine the determinants of the mother's level of knowledge about exclusive breastfeeding for infants 0-6 months at Sungai Kakap Public Health Center in 2019. The design of this study used a descriptive cross sectional approach. The population was mothers who breastfed infants aged 0-6 months in the work area as many as 107 respondents. The instrument used in this study was a questionnaire. The analysis used in this research is univariate and bivariate analysis. The sample technique in this study using purposive sampling. The results explained that there was a relationship between age and exclusive breastfeeding with $\mathrm{P}$ value $=0.027$, there was a relationship between parity and exclusive breastfeeding with $\mathrm{P}$ value $=0.016$, there was a relationship between education and exclusive breastfeeding with $\mathrm{P}$ value $=0.022$, there was a significant relationship between knowledge and exclusive breastfeeding with $\mathrm{P}$ value $=0.040$, there is a significant relationship between work and exclusive breastfeeding with $\mathrm{P}$ value $=0.010$, there is a significant relationship between husband's support and exclusive breastfeeding with $\mathrm{P}$ value $=0.002$. The conclusion from the study can be concluded that the determinant of the level of knowledge of breastfeeding mothers in the working area of Sungai Kakap Health Center is a small category of respondents.

\footnotetext{
${ }^{1}$ Dosen Akademi Kebidanan Panca Bhakti Pontianak

2 Dosen Akademi Kebidanan Panca Bhakti Pontianak
} 
Keywords: Knowledge, Breastfeeding Mother, Exclusive Breastfeeding

\section{Pendahuluan}

ASI Eksklusif adalah bayi hanya diberikan ASI saja tanpa makanan tambahan lainnya pada bayi berumur 0-6 bulan. ASI Eksklusif adalah makanan terbaik dan paling sempurna untuk bayi dengan kandungan gizi yang tinggi dan tidak bisa tergantikan susu formula sekalipun (Mashanafi, 2015).

WHO dan UNICEF sudah merekomendasikan hal itu sejak 1979 dalam pertemuan di Geneva tentang makanan bayi dan anak,antara lain berisi:"Menyusukan merupakan bagian terpadu dari proses reproduksiyang memberikan makanan bayi secara alamiah,serta merupakan dasar biologik dan psikologik yang dibutuhkan untuk pertumbuhan” (Ria Riksani, 2012) .

Waktu yang direkomendasi WHO untuk memberikan ASI Eksklusif selama 6 bulan bukan tanpa alasan. Dalam kajian WHO,yang melakkan penelitian sebanyak 3000 kali,menunjukan bahwa ASI menganudng semua nutrisi yang diperlukan bayi untuk bertahan hidup pada bulan pertama ,mulai hormon antibodi ,faktor kekebalan,hingga antioksidan.Berdasarkan hal tersebut, WHO kemudian mengbah ketentan mengenai ASI Eksklusif yang semula hingga 4 bulan menjadi 6 bulan (Azisya, 2010).

Manfaat ASI eksklusif untuk bayi 0-6 bulan adalah sebagai nutrisi, karena mengandung campuran yang tepat dari berbagai bahan makanan yang baik untuk bayi,meningkatkan kecerdasan, meningkatkan jalinan kasih sayang, meningkatkan daya tahan tubuh karena mengandung antibody yang kuat untuk mencegah infeksi dan membuat bayi menjadi kuat (Maryunani, 2017).

Berdasarkan data World Health Organization (WHO) cakupan ASI ekslusif di seluruh dunia hanya sekitar $36 \%$ selama periode 2007-2014. Berdasarkan hasil riskesdes 2012 cakupan pemberian ASI eksklusif di Indonesia sebesar 54,3\%, dimana persentase tertinggi terdapat di Provinsi NTB sebesar 79,7\%, dan terendah di Provinsi maluku sebesar 25,2\% (Balitbengkes, 2017)

Berdasarkan data Nasional tahun 2017 persentase bayi baru lahir yang mendapatkan ASI eksklusif sebesar 61,33\%. Angka tersebut sudah melampaui target renstra tahun 2017 yaitu 44\%. Persentase tertinggi cakupan pemberian ASI terdapat pada Nusa Tenggara Barat $(87,35 \%)$, sedangkan persentase terendah terdapat pada papua $(15,32 \%)$. Dan ada lima provinsi yang belum mencapai target renstra tahun 2017 (direktorat jenderal kesehatan masyarakat, kemenkes RI).

Masih rendahnya cakupan keberhasilan pemberian ASI Eksklusif pada bayi, baik didaerah perkotaan maupun di pedesaan, dipengaruhi banyak hal. Diantaranya rendahnya pengetahuan dan kurangnys informasi pada ibu dan keluarga mengenai pentingnya pemberian ASI Eksklusif, tata laksana rumah sakit ataupun tempat bersalin lain yang sering kali tidak melakukan bet-in 
(ibu dan bayi berada dalam satu kasur) atau pun rooming-in (ibu dan bayi berada dalam satu kamar atau rawat gabung), tidak jarang juga fasilitas kesehatan justru memberikan susu formula kepada bayi baru lahir, dan banyaknya ibu bekerja yang menganggap repot menyusui sambil kerja (Ria Riksani, 2012).

\section{Metode}

Desain penelitian ini menggunakan deskriptif dengan pendekatan cross sectional Populasi yaitu ibu yang menyusui bayi usia 0 6 bulan di wilayah kerja puskesmas sungai kakap sebanyak 107 responden. Instrumen yang digunakan dalam penelitian ini adalah kuesioner. Analisis yang digunakan dalam penelitian ini adalah analisis univariate dan Bivariate. Teknik sampel dalam penelitian ini menggunakan purposive sampling.

\section{Hasil dan Pembahasan}

\section{Tabel 1 Analisa Bivariat}

\begin{tabular}{|c|c|c|c|c|c|c|c|}
\hline \multirow{3}{*}{ Kategori } & \multicolumn{4}{|c|}{ Pemberian ASI Eksklusif } & \multirow{2}{*}{\multicolumn{2}{|c|}{ Total }} & \multirow{3}{*}{ P.Value } \\
\hline & \multicolumn{2}{|c|}{ Memberikan } & \multicolumn{2}{|c|}{ Tidak memberikan } & & & \\
\hline & $\mathrm{N}$ & $\%$ & $\mathrm{~N}$ & $\%$ & $\mathrm{n}$ & $\%$ & \\
\hline \multicolumn{8}{|l|}{ Usia } \\
\hline$<20$ & 2 & 1,4 & 25 & 92,6 & 27 & 100 & \multirow{2}{*}{0,027} \\
\hline$>20$ & 25 & 31,2 & 55 & 68,8 & 80 & 100 & \\
\hline \multicolumn{8}{|l|}{ Paritas } \\
\hline$\leq 2$ & 2 & 6,9 & 27 & 93,1 & 29 & 100 & \multirow{2}{*}{0,016} \\
\hline$>2$ & 25 & 32,1 & 53 & 67,9 & 78 & 100 & \\
\hline \multicolumn{8}{|l|}{ Pendidikan } \\
\hline SD - SMP & 13 & 41,9 & 18 & 58,1 & 31 & 100 & \multirow{2}{*}{0,022} \\
\hline SMA-PT & 14 & 18,4 & 62 & 81,6 & 76 & 100 & \\
\hline \multicolumn{8}{|l|}{ Pengetahuan } \\
\hline Rendah & 4 & 11,4 & 31 & 80,6 & 35 & 100 & \multirow{2}{*}{0,040} \\
\hline Tinggi & 23 & 31,9 & 49 & 68,1 & 72 & 100 & \\
\hline \multicolumn{8}{|l|}{ Pekerjaan } \\
\hline Tidak & 15 & 18,5 & 66 & 81,5 & 81 & 100 & \multirow{3}{*}{0,010} \\
\hline Bekerja & & & & & & & \\
\hline Bekerja & 12 & 46,2 & 14 & 53,8 & 26 & 100 & \\
\hline \multicolumn{8}{|l|}{ Dukungan } \\
\hline \multicolumn{8}{|l|}{ Suami } \\
\hline Tidak & 15 & 17,9 & 69 & 82,1 & 84 & 100 & \multirow{3}{*}{0,02} \\
\hline Mendukung & & & & & & & \\
\hline Mendukung & 12 & 52,2 & 11 & 47,8 & 23 & 100 & \\
\hline
\end{tabular}

Berdasarkan tabel diatas dapat berumur $>20$ tahun yang memberikan ASI diketahui bahwa responden yang berusia $\leq 20$ Tahun yang memberikan ASI Eksklusif ada 2 Eksklusif ada 25 orang $(31,2 \%)$. Hasil Uji statistik nilai $P$ value $=0,027$ yang berarti ada orang $(1,4 \%)$. Sedangkan responden yang hubungan yang bermakna antara usia dengan 
pemberian ASI Eksklusif. Sedangkan pada kategori paritas, responden yang mempunyai anak $\leq 2$ orang yang memberikan ASI Eksklusif ada 2 orang (6,9\%). Sedangkan responden yang mempunyai anak $>2$ orang yang memberikan ASI Eksklusif ada 25 orang $(32,1 \%)$. Hasil Uji statistik nilai $\mathrm{P}$ value $=0,016$ yang berarti ada hubungan yang bermakna antara Paritas dengan pemberian ASI Eksklusif.

Pada kategori pendidikan diketahui bahwa responden yang berpendidikan rendah yang memberikan ASI Eksklusif ada 13 orang $(41,9 \%)$. Sedangkan responden yang berpendidikan tinggi yang memberikan ASI Eksklusif ada 14 orang $(18,4 \%)$. Hasil Uji statistik nilai $\mathrm{P}$ value $=0,022$ yang berarti ada hubungan yang bermakna antara Pendidikan dengan pemberian ASI Eksklusif. Pada kategori pengetahuan dapat disimpulkan bahwa responden yang mempunyai pengetahuan kurang yang memberikan ASI Eksklusif ada 4 orang $(11,4 \%)$. Sedangkan responden yang mempunyai pengetahuan baik yang memberikan ASI Eksklusif ada 23 orang $(31,9 \%)$. Hasil Uji statistik nilai $\mathrm{P}$ value $=$ 0,040 yang berarti ada hubungan yang bermakna antara Pengetahuan dengan pemberian ASI Eksklusif.

Berdasarkan kategori pekerjaan pada tabel diatas, dapat dilihat bahwa responden yang tidak bekerja yang memberikan ASI Eksklusif ada 15 orang (18,5\%). Sedangkan responden yang bekerja yang memberikan ASI Eksklusif ada 12 orang (46,2\%). Hasil Uji statistik nilai $\mathrm{P}$ value $=0,010$ yang berarti ada hubungan yang bermakna antara Pekerjaan dengan pemberian ASI Eksklusif. Sedangkan kategori dukungan suami diketahui responden yang tidak didukung memberikan ASI Eksklusif ada 15 orang (17,9\%). Sedangkan responden yang mempunyai dukungan suami memberikan ASI Eksklusif ada 12 orang $(52,2 \%)$. Hasil Uji statistik nilai $\mathrm{P}$ value $=$ 0,002 yang berarti ada hubungan yang bermakna antara dukungan suami dengan pemberian ASI Eksklusif.

Hubungan Pengetahuan dengan

\section{Pemberian ASI Eksklusif}

Hasil uji statistik nilai $\mathrm{P}$ value $=0,040$ yang berarti ada hubungan antara pengetahuan dengan pemberian ASI Eksklusif. Ibu yang memiliki pengetahuan rendah memberikan ASI eksklusif sebanyak 4 orang $(11,4 \%)$ sedangkan yang memiliki pengetahuan tinggi memberikan ASI eklusif sebanyak 23 orang $(31,9 \%)$. Hasil penelitian ini sesuai dengan teori menurut ( Notoatmojdo,2007) yan menyatakan bahwa Pengetahuan merupakan faktor yang sangat penting untuk terbentuknya tindakan seseorang, apabila seseorang memiliki pengetahuannya yang baik tentang suatu hal maka kemunkinan besar ia akan bersikap memilih sesuatu hal tersebut namun sebaiknya apabila pengetahuannya kurang maka kemungkinan besar ia akan bersikap menolak untuk memilih hal tersebut.

Hal ini sejalan dengan penelitian Suhuda Hamsanikeda (2010), menyatakan bahwa sebagian besar ibu memiliki pengetahuan rendah tentang ASI Eksklusif .hal tersebut dapat menurunkan praktek 
pemberian ASI Eksklusif untuk bayi umur 1-6 bulan, karena pengetahuan sebagai modal dasar fakor pencetus untuk timbulnya perilaku atau tindakan. Padahal ASI Ekusif memberikan manfaat yang begitu besar bagi bayi,ibu dan juga bagi negara. Sedangkan menurut analisa penelitian menunjukan bahwa yang mempunyai pengetahuan baik dapat merubah perlilaku responden yang sebelumnya tidak memberikan ASI Eksklusif menjadi memberikan ASI Eksklusif.

\section{Hubungan Usia dengan Pemberian ASI Eksklusif}

Hasil uji statistik nilai $\mathrm{P}$ value $=0,027$ yang berarti ada hubungan antara usia dengan pemberian ASI Eksklusif. Sebagian besar responden yang berusia $<20$ tahun memberikan ASI Eksklusif sebanyak 2 orang $(1,4 \%)$ dibandingkan dengan responden yang berusia >20 tahun memberikan ASI Eksklusif sebanyak 25 orang $(31,2 \%)$. Dari hasil penelitian ini sesuai dengan teori menurut Winkjosastro (2007), yang menyatakan bahwa usia yang aman untuk hamil dan persalinan adalah usia 20-35 tahun maka ibu menyusui akan dengan mudah memberikan ASI untuk bayinya, namun menurut Hubertin Sri Purwanti, 2003 menyatakan bahwa usia 35 tahun atau lebih ibu yang melahirkan termasuk resiko tinggi dan rentan hubungan anemia dan masalah gizi yang dapat mempengaruhi pemberian ASI untuk bayinya.

Sedangkan Umur seorang wanita dapat mempengaruhi rendahnya tingkat pemahaman tentang pentingnya ASI selama 6 bulan pertama kelahiran bayi dikarenakan kurangnya pengetahuan yang dimiliki oleh para ibu mengenai segala plus nutrisi dan manfaat yang terkandung dalam ASI. Demikian halnya dengan kekahwatiran ibu yang menganggap bahwa produksi ASI tidak mencakupi kebutuhan makanan bayi. Anggapan ini sering menjadi salah satu kendala bagi ibu,yang akhirnya mencari alternatif lain dengan memberi susu pendamping makanan bayi lapar. Hal-hal tersebut menyebabkan terjadinya perubahan dari pola dasar pemberian ASI menjadi pemberian susu formula (Prasetyono,2009).

Sementara Menurut Siagian (2007), perilaku ibu akan lebih dewasa dengan meningkatnya umur sehingga mampu berfikir rasional, mengendalikan emosi dan toleransi terhadap pandangan orang lain, sedangkan teori yang dikemukakan oleh Notoatmdjo (2007) menyatakan bahwa pengetahuan yang baik dapat memotivasi timbulnya perubahan positif terhadap sikap, persepsi serta perilaku sehat individu atau masyarakat, dengan bertambahnya umur ibu akan meningkatkan kesadaran dalam menerapkan perilaku kelak ketika dia menyusui.

Namun Menurut Penelitian Rosidah (2010), mengatakan bahwa usia 25-35 tahun mempunyai tingkat pengetahuan baik dalam memberikan ASI Eksklusif. Sedangkan menurut analisa penelitian bahwa Usia antara 20-35 tahun merupakan usia yang terbaik untuk mengandung dan melahirkan serta kesiapan ibu untuk merawat bayinya dengan menyusui serta jika usia $<20$ tahun wanita 
merasa belum siap untuk menyusui dan berpendapat menyusui akan mengubah bentuk tubuh.

\section{Hubungan Paritas dengan Pemberian ASI}

\section{Eksklusif}

Hasil uji statistik nilai $\mathrm{P}$ value $=0,016$ yang berarti ada hubungan bermakna antara paritas dengan pemberian ASI Eksklusif. Sebagian besar responden yang mempunyai anak < 2 orang yang memberikan ASI eksklusif sebanyak 25 orang $(32,1 \%)$ dibandingkan dengan responden yang mempunyai yang mempunyai anak $>2$ orang yang memberikan ASI Eksklusif banyak 2 orang $(6,9 \%)$.

Dari hasil penelitian ini sesuai dengan teori menurut (Winkjosatro,2007) bahwa Paritas adalah jumlah anak yang telah dilahirkan oleh seorang ibu baik lahir hidup maupun lahir mati. Lebih tinggi paritas, lebih tinggi kematian maternal. Pada paritas tinggi dapat dikurangi atau dicegah dengan keluarga berencana. Sebagian kehamilan pada paritas tinggi adalah tidak direncanakan.

Hal ini sejalan dengan Penelitian Suhuda Hamsanikeda (2010), mengatakan bahwa jumlah anak yang $<2$ merupakan jumlah yang aman untuk melahirkan dan menyusui ASI Eksklusi efektif. Menurut analisa penelitian menyatakan bahwa Jumlah $<2$ anak merupakan angka paritas yang paling aman ditinjau dari sudut kematian martenal. Dengan pemberian ASI Eksklusif yang bermanfaat sebagai alat kontrasepsi alami dapat menunda kehamilan serta mampu menurunkan jumlah paritas sekaligus kematian maternal.

\section{Hubungan Pendidikan dengan Pemberian}

\section{ASI Eksklusif}

Hasil uji statistik diperoleh nilai $\mathrm{P}$ value $=0,022$ berarti ada hubungan yang bermakna antara pendidikan dengan pemberian ASI Eksklusif. Ibu yang mempunyai pendidikan tinggi memberikan ASI Eksklusif sebanyak 14 orang $(18,4 \%)$ sedangkan ibu yang mempunyai pendidikan rendah memberikan ASI Eksklusif sebanyak 13 0rang (41,9\%).

Dari hasil penelitian ini sesuai dengan teori menurut (Notoatmodjo. 2007), bahwa pendidikan seseorang berkaitan erat dengan pengetahuan yang dimilikinya,semakin tinggi pendidikan seseorang maka diharapkan tingkat pengetahuannya semakin banyak dan semakin mengerti tentang bagaimana cara mengkonsumsi makanan yang bergizi bagi ibu hamil sehingga bayi yang dilahirkannya diharapkan norma dan sehat,orang tua yang sehat dan gizinya baik akan mewariskan kesehatan yang baik pula pada anaknya.

Hal ini sejalan dengan penelitian Suhuda Hamsanikeda (2010), mengatakan bahwa pendidikan yang rendah sangat mempengaruhi pemberian ASI Eksklusif. Rendahnya pendidikan seorang ibu berpengaruh pada pola pikir yang baik. Sedangkan Menurut Penelitian Myrawati (2006), bahwa tingkat pendidikan ibu merupakan salah satu faktor penting dalam menentukan derajat kesehatan ibu dan bayinya, karena dengan bekal pendidikan yang cukup seorang ibu dapat memperoleh 
informasi serta memberikan perawatan yang lebih baik untuk dirinya dan bayinya.Kemudian Menurut analisa penelitian menujukan bahwa semakin tinggi tingkat pendidikan seseorang semakin maka semakin mudah menerima informasi sehingga makin banyak pula pengetahuan yang dimiliki.

\section{Hubungan Pekerjaan dengan Pemberian}

\section{ASI Eksklusif}

Hasil uji statistik nilai $\mathrm{P}$ value $=0,010$ yang berarti ada hubungan bermakna antara pekerjaan dengan pemberian ASI Eksklusif. Ibu yang bekerja dan memberikan ASI eksklusif sebanyak 12 orang $(46,2 \%)$ sedangkan ibu yang tidak bekerja dan memberikan ASI eksklusif sebanyak 15 orang $(18,5 \%)$.

Hasil penelitian ini sesuai sesuai dengan teori menurut (Roesli, 2004) yang menyatakan bahwa Bekerja bukan alasan untuk menghentikan pemberian ASI Eksklusif selama paling sedikit 4 bulan dan bila mungkin sampai 6 bulan. Dengan pengetahuan yang benaran tentang menyusui,perlengkapan memerahkan ASI dan dukungan lingkungan kerja seorang ibu yang bekerja dapat tepat memberikan ASI. Memberikan ASI merupakan hal yang terbaik baik bayi.

Hal ini sepandapat dengan pendapat (Azisya, 2010) bahwa menyusui bagi ibu bekerja memiliki berbagai keuntungan, diantaranya dapat meningkatkan produktifitas kerja, membuat ibu menjadi lebih percaya diri, menurunkan angka aborsi dikarenakan anak sakit, serta bisa juga menurunkan ketegangan ibu.

Tidak sekjana dengan penelitian Suparmanto (2008), pekerjaan adalah kegiatan yang dilakukan oleh ibu untuk mendapatkan kompensasi atau mendapat imbalan, namun pemberian susu formula tidak tergantung dari keberadaan ibu dirumah atau kedekatan ibu terhadap bayinya. Pada ibu yang bekerja dan harus meninggalkan rumahnya, mereka tidak mempunyai banyak waktu yang lebih dibandingkan ibu yang tidak bekerja, sehingga tidak leluasa untuk memberikan ASI pada bayinya, oleh sebab itu ibu memberikan susu formula pada bayinya.

Sedangkan menurut analisa penelitian menyatakan bahwa Bekerja sering kali dijadikan sebagai alasan ibu untuk tidak memberikan ASI Eksklusif. Tetapi bekerja bukanlah alasan untuk tidak memberikan ASI eksklusif karena dijaman sekarang banyak cara yang bisa ibu dilakukan untuk memberikan ASI Eksklusif.

\section{Hubungan Dukungan Suami dengan Pemberian ASI Eksklusif}

Hasil uji statistik nilai $\mathrm{P}$ volue $=0,002$ yang berarti ada hubungan antara dukungan suami dengan pemberian ASI Eksklusif. Ibu yang memiliki dukungan suami baik dan memberikan ASI Eksklusif sebanyak 12 orang $(17,9 \%)$ sedangkan ibu yang tidak didukungan suami memberikan ASI Eksklusif sebanyak 15 orang $(52,2 \%)$.

Hasil penelitian ini sejalan dengan pendapat ( Azissya, 2010) yang menyatakan bahwa Untuk mencapai kesuksesan dalam memberikan ASI Eksklusif dibutuhkan dari 
berbagai macam pihak, yaitu suami,orang tua atau saudara, teman sesama ibu menyusui, rekan kerja atau atasan ,serta asisten atau pengasuh.Dukungan suami atau merupakan faktor utama pendukung suksesnya menyusui. Peran aktif seseorang ayah yang mendukung istrinya menyusui selayaknya tidak hanya dilakukan ketika bayi sudah lahir, namun jauh-jauh harisebelumnya, saat ibu masih hamil.

Menurut analisa peneliti menyatakan bahwa Dukungan Suami merupakan motivasi yang sangat membantu ibu dalam memberikan ASI Eksklusif sehingga timbul rasa keinginan ibu untuk memberikan ASI secara Eksklusif dan ibu merasa di perhatikan oleh banyak orang serta dengan menyusui kebutuhan nutrisi ibu pun lebih diperhatikan oleh suami/keluarga.

\section{Kesimpulan}

a. Ada hubungan yang bermakna antara Pengetahuan dengan pemberian ASI Eksklusif Pada Bayi 0-6 bulan Di Puskesmas Sungai Kakap PadaTahun 2019 dengan $P$ value $=0,040$

b. Ada hubungan antara usia dengan Pemberian ASI Eksklusif Pada Bayi 0-6 bulan Di Puskesmas Sungai Kakap PadaTahun 2019 dengan $P$ value $=0,027$

c. Ada hubungan antara Paritas dengan pemberian ASI Eksklusif Pada Bayi 0-6 bulan Di Puskesmas Sungai Kakap PadaTahun 2019 dengan $P$ value $=0,016$

d. Ada hubungan antara Pendidikan dengan pemberian ASI Eksklusif Pada Bayi 0-6 bulan Di Puskesmas Sungai Kakap PadaTahun 2019 dengan $P$ value $=0,022$

e. Ada hubungan yang bermakna antara Pekerjaan dengan pemberian ASI Eksklusif Pada Bayi 0-6 bulan Di Puskesmas Sungai Kakap PadaTahun 2019 dengan $\mathrm{P}$ value $=0,010$

f. Ada hubungan yang bermakna antara dukungan suami dengan pemberian ASI Eksklusif Pada Bayi 0-6 bulan Di Puskesmas Sungai Kakap PadaTahun 2019 dengan $\mathrm{P}$ value $=0,002$

\section{Daftar Pustaka}

Azisya,Syasya.2010.Sukses Menyusui Meski Bekerja.Jakarta: Gema Insani

Baskoro, Anton. 2008. Asi Paduan Praktis Ibu Menyusui. Yogyakarta: Banyu Media

Damayanti, D.2010. Makanan Pendamping Asi. Jakarta: Pt Gramedia Pustaka Utama

Hastono,Sutanto Priyo.2007.Analisa Data Kesehatan. Jakarta: FKM UI

Kodrat, L. 2010. Dasyatnya Asi Dan Laktasi. Yogyakarta: Media Baca

Kusumawardhani.2010. Asi Bikin Anak Cerdas. Jakarta: Djambatan

2010. Metodelogi Penelitian Kesehatan. Jakarta: Rineka Cipta

Prasetyono,Dwi Sunar.2009. Buku Pintar Asi Eksklusif. Yogyakarta: Prestasi Pustakarya

Ria Riksani, 2012 . Keajaiban Asi(Air Susu $I b u)$. Jakarta: Dunia Sehat

Suhunda,H. 2010. Faktor-Faktor Yang Berhubungan Dengan Pemberian 
Asi Dengan Pengetahuan Ibu Terhadap Pemberian Asi Eksklusif. Jakarta: Urindo

Yuliarti,Nurheti.2010.Keajaiban Makanan Terbaik Untuk Kesehatan,Kecerdasan Dan Kelincahan Si Kecil. Yogyakarta: Andi Offset

Astuti, Sri. 2015. Asuhan Kebidanan Nifas \& Menyusui. Jakarta: Erlangga

Arikunto, Suharsimi. 2010. Prosedur Penelitian Suatu Pendekatan Praktis. Jakarta: Rineka Cipta

Ambarwati, Eni. 2008, Asuhan Kebidanan Nifas, Yogyakarta: Mitra Cendikia Press

Asih, Yusari 2016, Buku Ajar Asuhan Kebidanan Nifas Dan Menyusui. Jakarta Timur: Cv.Trans Info Media

Balitbengkes, 2017, Inisiasi Menyusui Dini, Asi Eksklusif Dan Manajemen Laktasi: Nuha Medika

Edyy, 2015, Asuhan Kebidanan Nifas, Jakarta: Rineka Cipta

Kristiyanasari, Weni, 2009, Asi Menyusui \& Sadari, Potorono, Bantul Yogyakarta: Nuha Medika

Kemenkes Ri. 2013, Riset Kesehatan Dasar, Riskesdes. Jakarta: Balitbang 2017, Kesehatan Dasar, Riskesdes. Jakarta: Kemenkes Ri

Listyaningrum, Utami, 2016, Payudara Dan Laktasi. Yogyakarta: Pustaka Pelajar

Maryunani Anik, 2012, Inisiasi Menyusui Dini, Asi Eksklusif Dan Manajemen
Laktasi: Jakarta: Rineka Cipta

Marimbi, Hanum 2010, Tumbuh Kembang, Status Gizi \& Imunisasi Dasar Pada Balita, Yogyakarta: Nuha Medika

Notoadmodjo, Soekidjo 2003, Perilaku Dan Pendidikan Kesehatan, Jakarta: PT Rineka Cipta

2010, Promosi Kesehatan. Jakarta: Rineka Cipta

Ningrum Puspita, Nyna 2015, Buku Ajar Asuhan Kebidanan Pada Masa Nifas Dan Menyusui. Jakarta Selatan: Salemba Medika

Rukiyah, Ai Yeyeh 2011. Konsep Kebidanan, Jakarta Timur: Cv Trans Info Media

Roesli, U. (2008). Manfaat Asi Dan Menyusui. Jakarta: Balai Penerbit Fakultas Kedokteran Universitas Indonesia

Walyani Elisabeth, Siwi 2015, Asuhan Kebidanan Masa Nifas Dan Menyusui, Yogyakarta: Pustaka Baru Press

Wiji, R.N.(2013). Asi Dan Pedoman Ibu Menyusui. Yogyakarta: Nuha Medika

World Health Organization (WHO). Global Asi Eksklusif Report 2015. 